\title{
CAROTENE YIELD IN SWEET POTATO AFTER POTASSIUM AND PHOSPHORUS FERTILISER APPLICATION ${ }^{1}$
}

\author{
SANDRA MARIA CRUZ NASCIMENTO ${ }^{2}$, ARTHUR BERNARDES CECÍLIO FILHO ${ }^{3}$, ALEXSANDRA SOUZA \\ NASCIMENTO DA SILVA ${ }^{2}$, PABLO FORLAN VARGAS ${ }^{4 *}$
}

\begin{abstract}
Sweet potato is one of the most important foods in the world. Among the different cultivated genotypes, it is worth highlighting those with orange pulp due to their ability to supply adequate amounts of provitamin A carotenoids to humans. This study evaluates the effect of potassium and phosphorus fertiliser application on carotenoid yield in sweet potatoes. Two experiments were carried out in São Luis City, Maranhão State, Brazil. The experimental design was a randomised block design, with six treatments for each of the studies $\left(0,30,60,90,120\right.$ and $150 \mathrm{~kg} \mathrm{ha}^{-1} \mathrm{~K}_{2} \mathrm{O}$ and $0,60,120,180,240$ and $\left.300 \mathrm{~kg} \mathrm{ha}^{-1} \mathrm{P}_{2} \mathrm{O}_{5}\right)$, with four replicates. Cultivar 'Beauregard' was used, which has high levels of carotenoids. Roots were harvested at 123 days after planting for both experiments. The following variables were evaluated: root fresh and dry weight, dry weight content, in addition to the yield and contents of total carotenoids, $\alpha$-carotene, $\beta$-carotene, 13 -cis $\beta$ carotene and 9 -cis $\beta$-carotene. With the average data of the evaluated characteristics, we performed analysis of variance and polynomial regression analysis. Potassium rates influenced carotenoid yield in sweet potato roots, with the rates of 73 to $77 \mathrm{~kg} \mathrm{ha}^{-1} \mathrm{~K}_{2} \mathrm{O}$ being recommended to maximise the production of total carotenoids, $\beta$ carotene, and $\alpha$-carotene. Phosphorus, in turn, influenced only total carotenoids, and is recommended at the rate of $174.09 \mathrm{~kg} \mathrm{ha}^{-1} \mathrm{P}_{2} \mathrm{O}_{5}$ to maximise the production of these nutrients.
\end{abstract}

Keywords: Ipomoea batatas. Carotenoids. Vitamin A.

\section{PRODUTIVIDADE DE CAROTENO EM BATATA-DOCE PELA ADUBAÇÃO POTÁSSICA E FOSFÓRICA}

RESUMO - A batata-doce é um dos alimentos de maior importância no mundo. Dentre os diferentes genótipos cultivados, merece destaque aqueles de polpa alaranjada, devido a sua capacidade de fornecer quantidades adequadas de carotenóides pró-vitamina A aos seres humanos. Assim, objetiva-se com o desenvolvimento deste trabalho avaliar o efeito de adubação com potássio e fósforo sobre os teores e produtividade de carotenóides em batata-doce. Foram realizados dois experimentos em São Luis, no Maranhão em delineamento em blocos ao acaso, sendo seis tratamentos para cada um dos estudos $\left(0,30,60,90,120\right.$ e 150 de $\mathrm{kg} \mathrm{ha}^{-1}$ de $\mathrm{K}_{2} \mathrm{O}$, e 0 , 60, $120,180,240$ e $300 \mathrm{~kg} \mathrm{ha}^{-1} \mathrm{de} \mathrm{P}_{2} \mathrm{O}_{5}$ ), com quatro repetições. Foi utilizada a cultivar 'Beauregard', que possui altos teores de carotenóides. Aos 123 dias após plantio, para ambos os experimentos, foram realizadas as colheitas das raízes, avaliando: massa fresca e seca da raiz, teor de massa seca, teores e produtividade de carotenóides totais, $\alpha$-caroteno, $\beta$-caroteno, 13 -cis $\beta$-caroteno e 9 -cis $\beta$-caroteno. Com os dados médios das características avaliadas, realizou-se análise de variância e análise de regressão polinomial. Doses de potássio influenciaram a rendimento de carotenóides em raízes de batata-doce, sendo recomendada as doses de 73 a 77 $\mathrm{kg} \mathrm{ha}^{-1}$ de $\mathrm{K}_{2} \mathrm{O}$ para maximizar a produção de carotenóides totais, $\beta$-caroteno e $\mathrm{p}$-caroteno. Para fósforo houve influência somente para carotenóides totais, sendo recomendada a de $174,09 \mathrm{~kg} \mathrm{ha}^{-1}$ de $\mathrm{P}_{2} \mathrm{O}_{5}$ para maximizar a produção desse elemento.

Palavras-chave: Ipomoea batatas. Carotenóides. Vitamina A.

\footnotetext{
${ }^{*}$ Corresponding author

${ }^{1}$ Received for publication in $02 / 11 / 2019$; accepted in 07/01/2019.

Paper extracted from the doctoral thesis of the first author.

${ }^{2}$ Instituto Federal do Maranhão, São Luís, MA, Brazil; scostacruz@bol.com.br - ORCID: 0000-0001-7054-0000, alexsandra.nascimento@ifma.edu.br-ORCID: 0000-0003-1891-142X.

${ }^{3}$ Department of Plant Production, Universidade Estadual Paulista, Jaboticabal, SP, Brazil; arthur.cecilio@unesp.br - 0000-0002-6706-5496.

${ }^{4}$ Tropical Root and Starches Center, Universidade Estadual Paulista, Botucatu, SP, Brazil; pablo.vargas@unesp.br - 0000-0002-5718-6403.
} 


\section{INTRODUCTION}

Sweet potato (Ipomoea batatas L.) is a vegetable that is among the most important foods worldwide, especially in developing countries, where it can provide food security to the population. This vegetable has a great phenotypic diversity derived from its genetic constitution, since it is a hexaploid species. This variability is most easily identified in the colours of the roots.

In recent years, orange-coloured sweet potatoes have gained prominence as a food capable of delivering sufficient amounts to meet the daily demand for vitamin A precursors to humans. One of the world's best-known orange pulp sweet potato cultivars is 'Beauregard'. This cultivar was developed by the Louisiana Agricultural Experiment Station and, according to Berni et al. (2015), has $120.2 \mu \mathrm{g}$ of $\beta$-carotene per gram of root.

Secondary metabolites $\alpha$-carotene, $\beta$-carotene and $\beta$-cryptoxanthin are known as provitamin $\mathrm{A}$ carotenoids (GAINO; SILVA, 2012). Vitamin A is the generic term for all compounds with the biological activity of retinol. This vitamin is a micronutrient essential for the maintenance of physiological functions of organisms, as it plays important roles in reproduction, the immune system, vision, cellular differentiation (PIRES et al., 2014) and in the maintenance of epithelial and mucosal structures lining the intestines, in addition to also being important for the respiratory tract and in the development of teeth and bones (SILVA et al., 2011).

The different carotenoids with provitamin A activity do not have the same biopotencies (COSTA; ORTEGA-FLORES; PENTEADO, 2001), and they are present in nature predominantly in the trans form. In turn, isomers in the cis form appear in much lower concentrations (KOBORI et al., 2010). Among these carotenoids, $\beta$-carotene stands out, because it has a provitamin A potential higher than others have (COSTA; ORTEGA-FLORES; PENTEADO, 2001).

Studies on soil fertiliser application are common in the agronomic environment, aiming mainly to reduce losses and increase fertiliser use efficiency in crops (SANTOS; VARGAS, 2012). This practice corresponds to one of the technologies used to increase crop yield and productivity (SOARES et al., 2015). However, nutrients affect not only the primary metabolism of plants, but they also influence the production of different secondary metabolites (GOBBO-NETO; LOPES, 2007), which affects the chemical composition of crops and products made therefrom (GRANT, 2014).

Phosphorus and potassium fertiliser application is an essential practice to obtain optimum levels of production, given that Brazilian soils are generally poor in these two macronutrients. Potassium is involved in several biochemical reactions necessary for plant metabolism (CASTRO et al., 2016), including those acting on stomatal regulation, cellular turgor and enzymatic activation (MALAVOLTA et al., 1997). Phosphorus, in turn, is active in respiration, photosynthesis (BAILEY et al., 2009) and nucleotide formation (DNA and RNA). When one of these elements is not present in satisfactory conditions for the plant, its deficiency generates anomalies due to changes in metabolism (SOUZA; CHAVES, 2016).

Considering the affirmation of Silva et al. (2011), who state that it is important to know the effect of $\mathrm{K}$ and $\mathrm{P}$ fertiliser application on carotenoid behaviour and based on the hypothesis that potassium and phosphorus fertiliser application affects carotenoid contents in sweet potato roots, this study evaluated the effect of potassium and phosphorus fertiliser application on carotenoid yield in sweet potatoes.

\section{MATERIAL AND METHODS}

Experiments were carried out from July 1 to October 31, 2011 (Experiment 1) and from September 3, 2011 to January 4, 2012 (Experiment 2), at the Federal Institute of Maranhão - IFMAMaracanã Campus, located in São Luis City, at $2^{\circ}$ $36^{\prime} 35^{\prime \prime}$ South latitude, $44^{\circ} 15^{\prime} 52^{\prime \prime}$ West longitude, and an altitude of 34 meters.

According to the Thornthwaite classification (1948), the climate of the region is type B1 WA, characterised as humid, with moderate water deficiency in the winter, between the months of June and September. The average maximum and minimum temperatures in the study period were $32.81{ }^{\circ} \mathrm{C}$ and $23.98{ }^{\circ} \mathrm{C}$, respectively, with $266.8 \mathrm{~mm}$ rainfall.

The soil of the area is a dystrocohesive Yellow Red Argisol of the Itapecuru Formation (EMBRAPA, 2013). Soil chemical characteristics and texture were measured before the installation of the study through soil samples collected from the 0 $20 \mathrm{~cm}$ layer. These samples were sent to the Laboratory of Soil Chemistry and Fertility of the State University of Maranhão.

The analysis presented a soil texture with $6 \%$, $8 \%$ and $86 \%$ of clay, silt and sand, respectively. Chemical analysis showed: $\mathrm{pH}\left(\mathrm{CaCl}_{2}\right)$ of 4.8; organic matter of $14 \mathrm{mg} \mathrm{dm}^{-3}$; $\mathrm{P}$ (resin) of $14 \mathrm{~g} \mathrm{dm}^{-3}$; $\mathrm{K}, \mathrm{Ca}, \mathrm{Mg}, \mathrm{Na}, \mathrm{Al}, \mathrm{Al}+\mathrm{H}$, and $\mathrm{CEC}$ of $0.3,3.0,4.0$, $0.4,0.0,24.0$, and $31.7 \mathrm{mmol}_{\mathrm{c}} \mathrm{dm}^{-3}$, respectively, and $24 \%$ base saturation.

Studies were performed in a randomised block design, with six treatments for each of the experiments (Experiment 1: 0, 30, 60, 90, 120 and $150 \mathrm{~kg} \mathrm{ha}^{-1} \mathrm{~K}_{2} \mathrm{O}$; and Experiment 2: 0, 60, 120, 180, 240 and $300 \mathrm{~kg} \mathrm{ha}^{-1} \mathrm{P}_{2} \mathrm{O}_{5}$ ), with four replicates each. The area of the experimental unit was $2.40 \mathrm{~m}$ wide and $3.50 \mathrm{~m}$ long, comprising three rows spaced 0.80 $\mathrm{m}$ apart, with ten plants spaced $0.35 \mathrm{~m}$ apart. Data 
were collected only for the eight central plants of the plot, with a useful area of $2.24 \mathrm{~m}^{2}$, the others were considered border plants.

'Beauregard' sweet potato was used, which is an American cultivar developed by the Louisiana Agricultural Experiment Station. This cultivar has a vegetative cycle between 90 and 130 days, elongated and uniform roots, and a purple-red bark, being smooth and with an intense orange colour on the inside, indicative of high beta-carotene content.

Liming was performed in the total area 60 days before the first experiment with limestone containing $32 \% \mathrm{CaO}, 15 \% \mathrm{MgO}$ and $95 \% \mathrm{TRNP}$ to raise thesoil base saturation to $60 \%$ and $\mathrm{Mg}$ content to at least $10 \mathrm{mmol}_{\mathrm{c}} \mathrm{dm}^{-3}$ (CASALI, 1999). This operation was followed by a ploughing and harvesting to incorporate the input.

Stems containing four buds were removed from the apical part of mother plants at the EMBRAPA experimental field in Coroatá-MA and were subsequently placed in 50-cell polystyrene trays containing organic substrate. After 25 days, they were transplanted to furrows.

For crop establishment, $20 \mathrm{~cm}$ deep furrows were opened. For the potassium experiment, $30 \mathrm{~kg}$ ha $^{-1} \quad \mathrm{~N}$ (urea), $180 \quad \mathrm{~kg} \quad \mathrm{ha}^{-1} \quad \mathrm{P}_{2} \mathrm{O}_{5} \quad$ (triple superphosphate) and $10 \mathrm{t} \mathrm{ha}^{-1}$ tanned bovine manure were applied. Following the experimental planning, potassium fertiliser application was carried out at planting, with potassium chloride as a source. For the phosphorus experiment, $30 \mathrm{~kg} \mathrm{ha}^{-1} \mathrm{~N}$ (urea), $90 \mathrm{~kg}$ ha ${ }^{-1} \mathrm{~K}_{2} \mathrm{O}$ (potassium chloride), and $10 \mathrm{t} \mathrm{ha}^{-1}$ tanned bovine manure were applied. Phosphorus fertiliser application was also carried out at planting, with triple superphosphate as a source. Subsequently, furrows were manually rebuilt with the aid of a hoe.

Irrigations were carried out according to the need of the crop, observing its evapotranspiration values. Thirty days after transplanting the seedlings, topdressing fertiliser application was performed by applying $30 \mathrm{~kg} \mathrm{ha}^{-1} \mathrm{~N}$ as urea (DAT) (CASALI, 1999).

Pests (whitefly and cochineal) were controlled chemically, and weeds were removed through three manual weedings; two of these were performed in the furrows, at 30 and $60 \mathrm{DAT}$, and one was performed in between furrows, at 45 DAT.

Sweet potato roots were harvested at 123 DAT for both experiments, the following variables were evaluated:

a) Root fresh weight: the roots of the eight plants in the useful area $\left(2.24 \mathrm{~m}^{2}\right)$ were harvested and were then washed and put to dry in the shade for one day. Subsequently, the roots were weighed and the values converted to $\mathrm{kg} \mathrm{ha}^{-1}$.

b) Root dry weight: two roots from the useful area were weighed, cut into small pieces, placed in paper bags and put to dry in an oven with forced air circulation at $65{ }^{\circ} \mathrm{C}$ until constant weight. Subsequently, they were again weighed and the values converted to $\mathrm{kg} \mathrm{m}^{-2}$.

c) Root dry mass content was calculated by dividing root dry weight by root fresh weight.

d d) Carotenoid content: after determining root dry weight, a portion was used to quantify the levels of total carotenoids, $\alpha$-carotene, $\beta$-carotene, 13 -cis $\beta$-carotene and 9-cis $\beta$-carotene. Molecules were analysed through high-performance liquid chromatography according to Pacheco et al. (2009).

e) Carotenoid yield: with the values of root dry weight and carotenoid content, we estimated the total production of the elements per hectare $\left(\mathrm{g} \mathrm{ha}^{-1}\right)$.

The data obtained for the evaluated characteristics were submitted to analysis of variance by the $\mathrm{F}$ test $(\mathrm{p}<0.05)$. Polynomial regression analysis was performed when the effects of nutrient rates were significant, opting for the higher degree equation that best fit the average of the data. The statistical program SIVAR (FERREIRA, 2014) was used for statistical analysis, and the program Microsoft $^{\circledR}$ Excel $^{\circledR}$ (2013) was used to generate graphs.

\section{RESULTS AND DISCUSSION}

\section{Potassium}

The average values for the contents of total carotenoids, $\alpha$-carotene, $\beta$-carotene, 9 -cis $\beta$-carotene and the production of 9 -cis $\beta$-carotene per hectare (Figures $1 \mathrm{~A}, 1 \mathrm{~B}$ and $1 \mathrm{~F}$ ) as a function of $\mathrm{K}_{2} \mathrm{O}$ rates applied to the soil did not fit any regression model. The average values were, respectively, 10,711.70, $9,160.46,533.87$ and $115.34 \mu \mathrm{g} 100 \mathrm{~g}^{-1}$ and $6.32 \mathrm{~g}$ $\mathrm{ha}^{-1}$.

The content of 13 -cis $\beta$-carotene as a function of $\mathrm{K}$ rates fit a decreasing linear regression model (Figure 1B), with a $55.40 \%$ correlation. The highest content was observed when no fertiliser application was performed $(241.8 \mu \mathrm{g} / 100 \mathrm{~g})$. There was a decrease of $0.59 \mu \mathrm{g}$ for each $\mathrm{kg}$ of $\mathrm{K}_{2} \mathrm{O}$ fertiliser applied, resulting in a content of $152.10 \mu \mathrm{g} 100 \mathrm{~g}^{-1}$ when using $150 \mathrm{~kg} \mathrm{~K}_{2} \mathrm{O} \mathrm{ha}^{-1}$. The behaviour verified for the content of 13-cis $\beta$-carotene isomer was similar to the behaviour of the root dry content of 'Beauregard' sweet potato (Figure 1D), with a $42.80 \%$ correlation. For the latter variable, the lowest value was also established with the highest $\mathrm{K}_{2} \mathrm{O}$ fertiliser application $\left(150 \mathrm{~kg} \mathrm{ha}^{-1}\right)$. The highest value observed for root dry mass content occurred when no $\mathrm{K}_{2} \mathrm{O}$ fertiliser application was performed, with $25.61 \%$ dry mass. Maximum fertiliser application yielded the lowest dry weight content Notwithstanding, the difference in the content was only $1.51 \%$. It is inferred that the highest dry weight content was reached due to the concentration effect, since the lowest root production was also observed. Thus, in the present study, the increase in $\mathrm{K}_{2} \mathrm{O}$ rates has a negative influence on dry weight and 13-cis $\beta$ -

Rev. Caatinga, Mossoró, v. 32, n. 3, p. 851 - 857, jul. - set., 2019 
carotene content in 'Beauregard' sweet potatoes.

The average values of root weight and root dry weight fit a quadratic regression equation (Figure 1C). Maximum root weight (24.36 $\left.\mathrm{t} \mathrm{ha}^{-1}\right)$
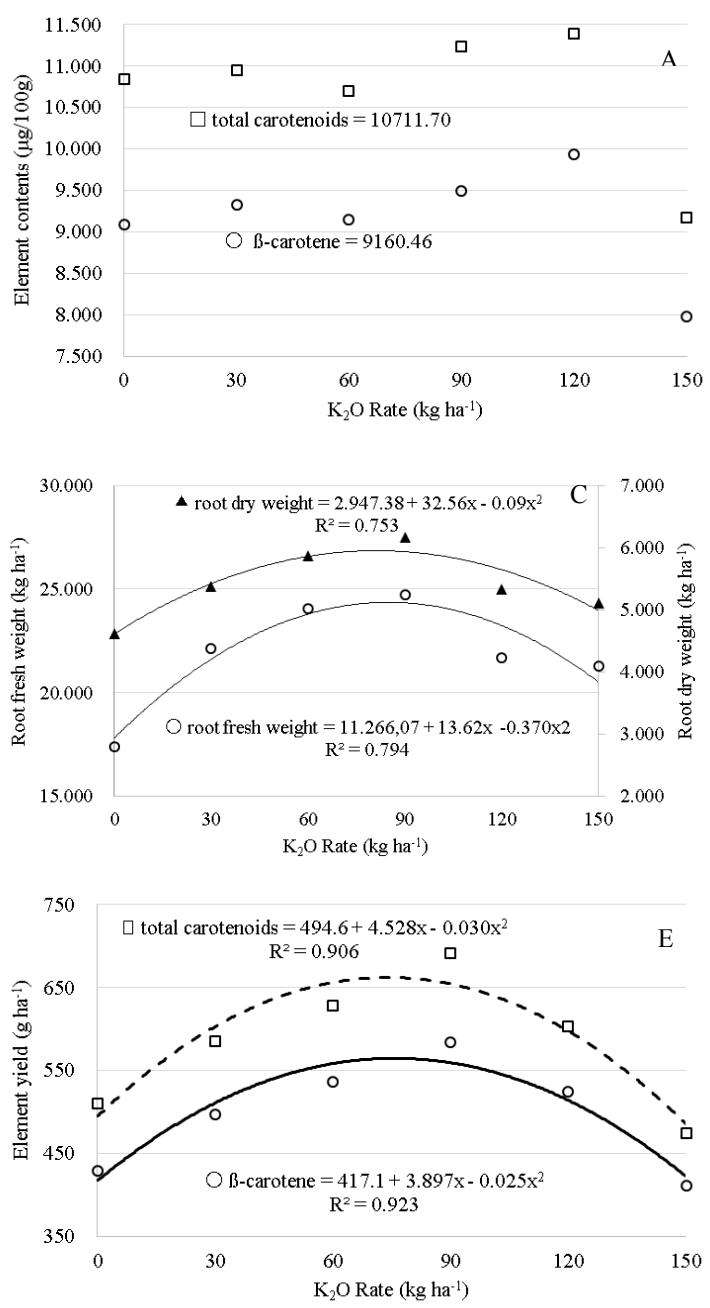

Figure 1. Total carotenoid content, $\beta$-carotene (A), $\alpha$-carotene, 13 -cis- $\beta$-carotene and 9 -cis $\beta$-carotene (B), root fresh weight and root dry $(C)$, root dry weight content $(D)$, total carotenoid yield and $\beta$-carotene $(E), \beta$-carotene yield, 13 -cis $\beta$-carotene and 9-cis $B$-carotene $(\mathrm{F})$, as a function of potassium rates.

For total carotenoids, $\alpha$-carotene, $\beta$-carotene and 13-cis $\beta$-carotene, similar behaviour was observed for root fresh and dry weight per hectare (Figures $1 \mathrm{E}$ and $1 \mathrm{~F}$ ). These variables fit a quadratic polynomial regression model, and maximum total carotenoid yield (665.45 $\mathrm{g} \mathrm{ha}^{-1}$, Figure 1E) was observed with the rate of $75.46 \mathrm{~kg} \mathrm{~K}_{2} \mathrm{O}$. In many countries, the highest contribution of vitamin A intake $(82 \%)$ comes from carotenoids contained in plant-based foods (Kim et al., 2014). Therefore, as verified in the present study, management of potassium fertiliser application can contribute to increase total carotenoid yield, thus enabling a higher intake of carotenoids by the population.

For $\alpha$-carotene, $\beta$-carotene, and 13-cis $\beta$ carotene, maximum yields were obtained, respectively, for the rates of 77.94, 73.38 and 58.78 $\mathrm{kg} \mathrm{K} \mathrm{K}_{2}$ Oresulting in 568.96, 37.92 and $12.88 \mathrm{~g} \mathrm{ha}^{-1}$. Thus, the range of 58.78 to $77.94 \mathrm{~kg} \mathrm{ha}^{-1} \mathrm{~K}_{2} \mathrm{O}$ occurred with a fertiliser application of $84.9 \mathrm{~kg} \mathrm{ha}^{-1}$ $\mathrm{K}_{2} \mathrm{O}$, while maximum root dry weight $\left(5.95 \mathrm{t} \mathrm{ha}^{-1}\right)$ was obtained with a fertiliser application of $81.95 \mathrm{~kg}$ ha $^{-1} \mathrm{~K}_{2} \mathrm{O}$.
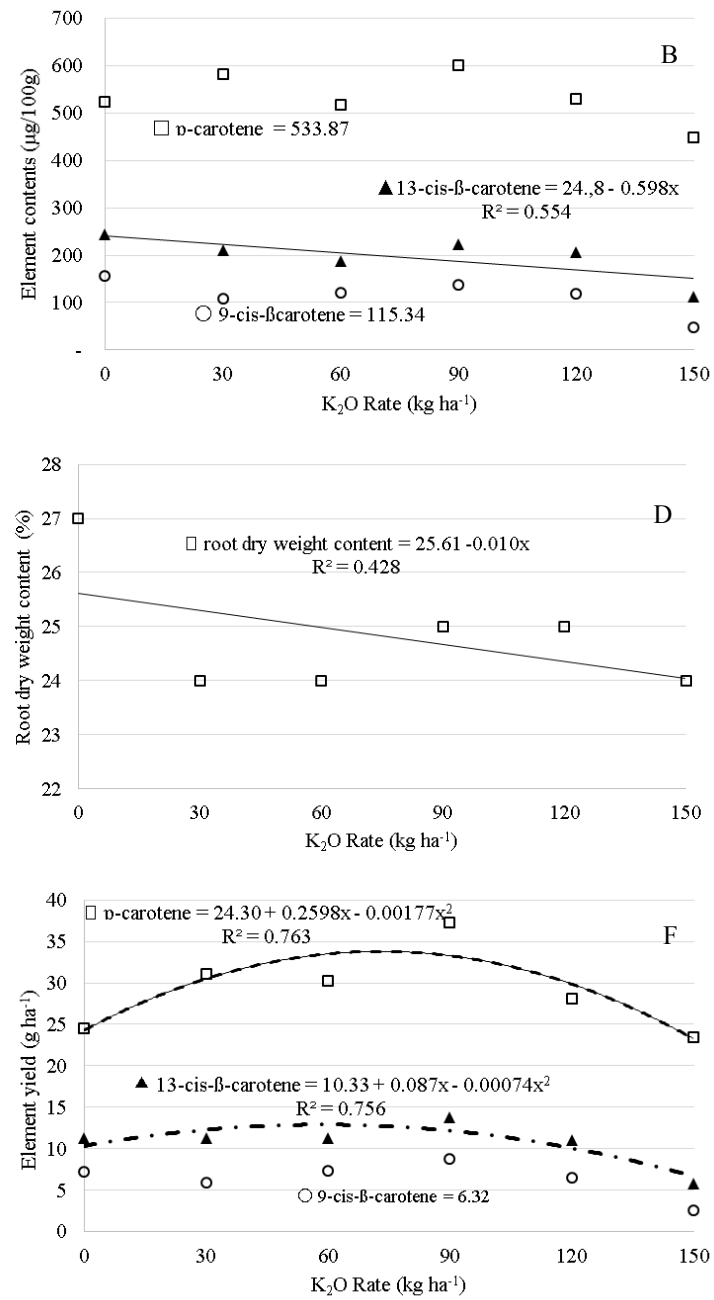

maximised the yield of these carotenoids. As reported by Silva et al. (2010), in recent years, increasing attention has been devoted to the role of diet in human health. Several epidemiological studies have indicated that high intake of vegetables is associated with a reduced risk of a variety of chronic diseases such as atherosclerosis and cancer. These effects have been particularly attributed to bioactive compounds that have antioxidant activity (Silva et al., 2010). It is noteworthy that higher yields of these compounds ( $\alpha$-carotene, $\beta$-carotene and 13 -cis $\beta$ carotene) can be achieved in 'Beauregard' sweet potato by potassium fertiliser application.

In this way, potassium increases the yield of sweet potato roots to a certain extent, from which a loss of yield begins with increasing fertiliser application rates. However, this inflection point for total carotenoids and their fractions (mentioned above) occurs with a fertiliser applicer application, 
on average, of $13.56 \mathrm{~kg} \mathrm{~K}_{2} \mathrm{O}$ ha $^{-1}$ lower. Therefore, there is a dichotomy between producing a higher volume and achieving a better quality of sweet potato roots. Currently, for the marketing forms that govern the sweet potato production chain, there is no doubt which criterion is more economically feasible for the rural entrepreneur. Notwithstanding, there is an increasing demand by consumers for foods with higher nutritional contents and bioactive compounds.

\section{Phosphorus}

The content of total carotenoids, $\beta$-carotene, 13-cis $\beta$-carotene, 9-cis $\beta$-carotene and yield per hectare of $\alpha$-carotene, $\beta$-carotene, 13 -cis $\beta$-carotene and 9-cis $\beta$-carotene did not fit polynomial
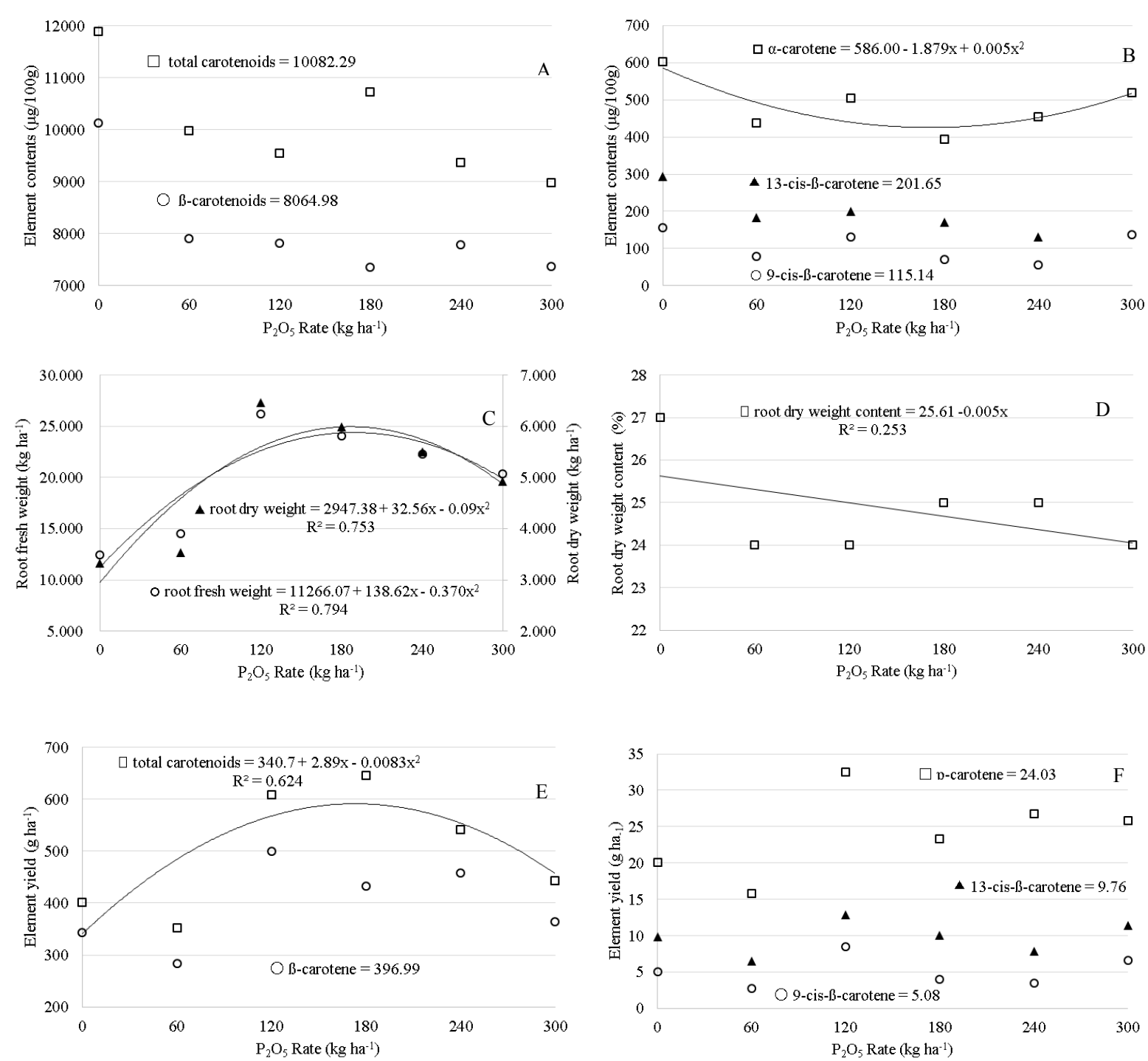

Figure 2. Total carotenoid content, $\beta$-carotene (A), $\alpha$-carotene, 13 -cis- $\beta$-carotene and 9 -cis $\beta$-carotene (B), root fresh weight and root dry $(\mathrm{C})$, root dry weight content $(\mathrm{D})$, total carotenoid yield and $\beta$-carotene $(\mathrm{E}), \beta$-carotene yield, 13 -cis $\beta$-carotene and 9 -cis $\beta$-carotene $(\mathrm{F})$, as a function of phosphorus rates.

regression models; that is, $\mathrm{P}$ rates did not influence these characteristics. The average values observed were $10,082.29,8,064.98,201.65$ and $115.14 \mu \mathrm{g} 100$ $\mathrm{g}^{-1}$ and 396.99, 24.03, 9.76, and $5.08 \mathrm{~g} \mathrm{ha}^{-1}$, respectively (Figures $2 \mathrm{~A}$ and $2 \mathrm{~B}$ ).

The highest $\alpha$-carotene content was observed when no phosphorus fertiliser application was performed, 586.00 $\mu \mathrm{g} 100 \mathrm{~g}^{-1}$ (Figure 2B). The lowest value found for this pigment was obtained with the rate of $187.90 \mathrm{~kg} \mathrm{ha}^{-1} \mathrm{P}_{2} \mathrm{O}_{5}$.

Root fresh and dry yield fit a quadratic regression model, with maximum values of 24,249.51 and 5,892.25, respectively (Figure 2C). These values were reached using 180.88 and 187.32 $\mathrm{kg} \mathrm{ha}{ }^{-1} \mathrm{P}_{2} \mathrm{O}_{5}$ for root fresh and dry weight, respectively. 
The only pigment that fit a regression model was total carotenoids, with the second degree equation representing the best data distribution. Maximum carotenoid yield (592.26 g) was obtained with a fertiliser application of $174.09 \mathrm{~kg} \mathrm{ha}^{-1} \mathrm{P}_{2} \mathrm{O}_{5}$ (Figure 2E). According to Berni et al. (2015), Brazil is investing in the development of new orange sweet potato cultivars adapted to national conditions. However, even after the development of these cultivars, agronomic biofortification through phosphorus fertiliser application will be an important tool to raise the levels of bioactive compounds in sweet potatoes.

There is a difference of 6.79 and $13.23 \mathrm{~kg}$ of $\mathrm{P}_{2} \mathrm{O}_{5}$ between the maximum production of total carotenoids and root fresh and dry weights, respectively. Currently, sweet potato is not yet exploited for the production of carotenoids. Nonetheless, there is an immense field to be explored, given the possibility of using carotene as an additive in the food industry (natural dye). In poultry and aquaculture, carotene can be used to provide colouring to egg yolks and to intensify the colouring of the meat of crustaceans raised in captivity for human consumption. In the pharmaceutical and nutraceutical industry, carotene can be used to prevent photosensitivity disorders, cardiovascular diseases, diabetes, vision disorders, cancer, neurological disorders and immunological diseases (MESQUITA et al., 2017).

\section{CONCLUSIONS}

Potassium rates influence carotenoid production in 'Beauregard' sweet potato roots in São Luis/MA. Rates of $73-77 \mathrm{~kg} \mathrm{ha}{ }^{-1} \mathrm{~K}_{2} \mathrm{O}$ are recommended to maximise the production of total carotenoids, $\alpha$-carotene and $\beta$-carotene. In turn, phosphorus influences only total carotenoids, with the rate of $174.09 \mathrm{~kg} \mathrm{ha}^{-1} \mathrm{P}_{2} \mathrm{O}_{5}$ being recommended to maximise its production.

\section{REFERENCES}

BAILEY, J. S. et al. An evaluation of nutritional constraints on sweet potato (Ipomoea batatas) production in the central highlands of Papua New Guinea. Plant and Soil, v. 316, n. 1-2, p. 97-105, 2009.

BERNI, B. et al. Comparison of content and in vitro bioaccessibility of provitamin a carotenoids in home cooked and commercially processed orange fleshed sweet potato (Ipomea batatas Lam). Plant Foods Human Nutrition, v. 70, n. 1, p. 1-8, 2015.

CASALI, V. W. D. Sugestão de adubação de hortaliças: In: RIBEIRO, A. C.; GUIMARÃES, P. T. G.; ALVAREZ, V. V. H. Recomendação para uso de corretivos e fertilizantes em Minas Gerais. Viçosa: CFSEMG, v. 5, 1999. cap. 18, p. 171-208.

CASTRO, B. F. et al. Produção de rabanete em função da adubação potássica e com diferentes fontes de nitrogênio. Revista de Ciências Agrárias, v. 39, s/n., p. 455-472, 2016.

COSTA, M. A. L.; ORTEGA-FLORES, C. I.; PENTEADO, M. V. C. Conversão dos isômeros do $\beta$ -caroteno. Nutrire, v. 21, n. 1, p.73-86, 2001.

EMPRESA BRASILEIRA DE PESQUISA AGROPECUÁRIA - EMBRAPA. Sistema brasileiro de classificação de solos. 2 ed. Rio de Janeiro, RJ: Embrapa/CNPS, 2013. 353 p.

FERREIRA, D. F. Sisvar: a Guide for its Bootstrap procedures in multiple comparisons. Ciência \& Agrotecnologia, v. 38, n. 2, p. 109-112, 2014.

GAINO, N. M.; SILVA, M. V. Disponibilidade de carotenóides. Nutrire, v. 37, n. 3, p. 227-244, 2012.

GOBBO-NETO, L.; LOPES, N. P. Plantas medicinais: fatores de influência no conteúdo de metabólitos secundários. Química Nova, v. 30, n. 2, p. 374-381, 2007.

GRANT, C. Adubação para qualidade nutricionais dos alimentos. IPNI - Informações Agronômicas, $\mathrm{n}^{\circ} 145$, p. 14-17, 2014. Disponível em: $\quad<$ http://www.ipni.net/publication/iabrasil.nsf/0/5FFABE3256066CCF83257CB3007211 3C/\$FILE/Page14-17-145.pdf $>$. Acesso em: 23 mai. 2017.

KIM, H. W. et al. Effect of processing conditions on the content of cis/trans carotene isomers as provitamin A carotenoids in Korean sweet potato varieties. Food Composition and Analysis, v. 65, n. 7, p. 821-826, 2014.

KOBORI, C. N. et al. Teores de carotenóides em produtos de tomate. Revista do Instituto Adolfo Lutz, v. 69, n. 1, p. 78-83, 2010.

MALAVOLTA, E. et al. Avaliação do estado nutricional das plantas: princípios e aplicações. 2. ed. Revista. Atual. Piracicaba, SP: POTAFOS, 1997, $319 \mathrm{p}$.

MESQUITA, S. S. et al. Carotenóides: Propriedades, Aplicações e Mercado. Revista Virtual de Química, v. 9 , n. 2 , p. $672-688,2017$.

MICROSOFT $^{\circledR} \quad$ EXCEL $^{\circledR}$. Microsof Office Professional Plus, Santa Rosa, California. 2007. 
PACHECO, S. et al. Preparo de padrões analíticos de alta pureza usando cromatografia líquida de alta eficiência em escala analítica. In: SIMPÓSIO DE SEGURANÇA ALIMENTAR, 3., 2010, Florianópolis. Anais... Florianópolis: SBCTA, 2010.

PIRES, P. C. C. et al. Retinol sérico, condição clínica e perfil dietético relacionado à vitamina a em préescolares. HU Revista, v. 40, n. 3-4, p. 157-164, 2014.

SANTOS, R.; VARGAS, G. R. Efeito da adubação potássica na produtividade da soja. Publicatio UEPG: Ciências Exatas e da Terra, Agrárias e Engenharias, v. 18, n. 2, p. 79-84, 2012.

SILVA, E. C. et al. Teores de $\beta$-caroteno e licopeno em função das doses de fósforo e potássio em frutos de diferentes genótipos de tomateiro industrial. Bioscience Journal, v. 27, n. 2, p. 247-252, 2011.

SILVA, M. L. C. et al. Compostos fenólicos, carotenóides e atividade antioxidante em produtos vegetais. Semina: Ciências Agrárias, v. 31, n. 3, p. 669-682, 2010.

SOARES, L. A. A. et al. Fitomassa e produção do girassol cultivado sob diferentes níveis de reposição hídrica e adubação potássica. Revista Brasileira de Engenharia Agrícola e Ambiental, v. 19, n. 4, p. 336-342, 2015.

SOUZA, R. S.; CHAVES, L. H. G. Doses de fósforo e potássio no desenvolvimento da cultura de Crambe abyssinica. Revista Verde de Agroecologia e Desenvolvimento Sustentável, v. 11, n. 2, p. 71-75, 2016. 